\title{
Social Media for Networking and Participatory Professional Learning
}

\author{
McLoughlin, Catherine ${ }^{\mathrm{a}}$
}

${ }^{\mathrm{a}}$ Faculty of Education and Arts, Australian Catholic University, Canberra, Australia.

\begin{abstract}
There is widespread acceptance of the need for professional learning opportunities and support for teachers and for academics transitioning into the higher education workforce. In Australia and globally, social networking sites (SNS) provide teachers with formal and informal networking opportunities. While higher education institutions are responding to an everchanging digital environment, scholarly work aimed at understanding optimal use of, and interaction with new Web 2.0 capabilities is a pressing area of concern among academics. Limited studies are available on how and why teachers in higher education employ social networking tools to create learning networks, share professional ideas and build creative collegiality. This scoping review article investigates motivations for the adoption of SNS in higher education and the benefits and opportunities presented by social networking tools such as blogs and Twitter in teacher professional learning and practice. Results show that academics are interested in connecting with peers, sharing knowledge and networking in open participatory forums as means of building community and accessing resources. The findings indicate that the affordances of microblogging and SNS are valued by academics and that they appreciate the immediacy, relational aspects and interactions that expand their professional networks.
\end{abstract}

Keywords: informal learning, networking, Twitter, social networks, knowledge, sharing. 


\section{Introduction and aim}

'Social media' refers to a set of digital tools that support communication and interaction among users. Digital tools - wikis, blogs and microblogging - facilitate the creation and sharing of content and enable many-to-many dialogue. The perception of social media in education has changed rapidly and is no longer viewed as a passing trend or fashion, so having a flexible and well-managed presence through Facebook, LinkedIn, or Google+ are regarded as part of one's professional profile. Microblogging has become essential for universities to enable rapid communication, digital and flexible learning environments and advertising to secure a place in the global educational marketplace.

Recently, the Council of Australian Directors of Academic Development (nd) ) advocated use of digital tools and Social Media Toolkit noting three key attributes of social media channels that make them highly effective as communication channels:

- Personalization - content tailored to individual needs

- Presentation - timely and relevant content accessible in multiple formats and contexts

- $\quad$ Participation - engaging partners and the public who contribute content in meaningful ways.

What has been learnt from socio-technical systems like email and microblogging is their capacity to support an array of social, cognitive and communicative needs. Social Networking Sites (SNS) like Facebook, MySpace, Twitter, and Pinterest are web-based services that allow individuals to: 1) construct a public or semi-public profile within a bounded system; (2) create a list of other users with whom they share a connection; and (3) view and edit their list of connections (Boyd \& Ellison, 2007: 211). Twitter, founded in 2006, has provided a number of educational benefits, such as sharing information and collaborating around common interests. As the service can be used from any smartphone or mobile device, it is widely used for public dialogue in world-wide events. Any Twitter user can "follow" any other, and there is no need or expectation that the person being followed will reciprocate. Twitter has impacted on communication trends in significant ways by reducing temporal and spatial constraints, and is not only used by journalists, politicians and celebrities, but also by academics wishing to connect with colleagues and keep up to date with professional trends. The focus of this article is to survey the educational research literature to examine how social media and microblogging are used for professional networking among teachers and academics. Current literature is inconclusive in identifying the contribution of social media platforms to professional learning and of online networking activity among academics, and how microblogging in particular, enhances productivity. The paper is intended to contribute to this important area in higher education practices. 


\section{Challenges presented by social media in educational contexts}

In this article, networks are defined as the tools, artefacts and interpersonal processes that facilitate communication and sharing of interests by groups. Such virtual networks connect teachers to other individuals globally with the aim of sharing resources, offering support, feedback, and opportunities for collaboration. SNS' may also enable access to information, new ideas and connection with others around the world who share mutual interests and goals (Lock, 2006). There is acceptance across the higher education sector that that specialist knowledge and skills are required to carry out strategic development work and that the role of the academics (educational/faculty) are changing within the academic profession (Di Napoli, et al, 2010; Schroeder et al 2010). There are pressures on university teachers to change and adapt their pedagogies to include social media and digital devices. In the past, professional development was formal and top-down, characterized by face-toface workshops and training. Now it is recognized that knowledge is experientially acquired and can occur through informal conversations and practice-based activities, peer-learning and mentoring. As increasing connectivity is part of the landscape in the $21^{\text {st }}$ century, the importance of networking, along with other forms of social exchange are recognized as offering powerful opportunities for sharing and professional support. In the Australian context, teaching staff in higher education have diverse roles including teaching and assessment, research and publication, while also ensuring that pedagogic practices align with policy and maintaining best practice in e-learning (Mewburn \& Thompson, 2013). Higher education teachers are also witnessing a major shift and the need to adopt revised modes of working, such as collaborative teams, shared discourse, partnerships with students and learning communities that enable just-in-time and informal learning (Veletsianos, 2012). Teaching and learning terms, such as 'understanding information' and acquisition of knowledge', have been replaced by concepts such as activity, participation, and situational knowledge creation (Paavola et al, 2004). Pervasive communication technologies have increased the emphasis on collaboration and exchange, emphasizing the importance of social networks as sources of professional learning, problem solving and innovation. While learning in networks is not new, the adoption of digital tools and microblogging has increased the ease of communication and potential for informal learning in online spaces. Due to the ubiquity of digital tools, the focus for the teaching profession has become one of horizon broadening and constant review of practices for communication, research and professional networking.

To meet these demands, teaching staff are adopting social media platforms in their pedagogy, research practices, and for cross-faculty dialogue (Mewburn \& Thompson, 2013). In relation to Twitter, Prestridge (2013:724) advocates use of microblogging by demonstrating that this medium offers staff and students opportunities for improved social and cognitive engagement. While social networking tools are being widely adopted there 
remain important questions about the variety of ways in which digital tools and social networking services are being used in higher education to improve and support the professional work of academics. The aim of the paper is to address this gap.

\section{Social Networks and their potential for professional learning}

The rise of social media services offers new possibilities for the creation of "affinity spaces" where participatory cultures of collaboration and sharing thrive (Gee, 2007; Jenkins et al, 2006). Much research shows that SNSs and microblogging amplify the communication possibilities and supplement interpersonal contact, participation, and community commitment (Carpenter \& Krutka, 2014). These tools make possible synchronous and asynchronous communication, distributed collaboration and social interaction, and are already having a transformative effect in higher education, triggering changes in how we communicate and learn. Moreover, the uptake of social software tools has gained momentum in all sectors of education (Lee \& McLoughlin 2010) by enhancing communication capabilities through increased connectivity, customization, personalization, and rich opportunities for informal networking.

Research evidence indicates that SNS (Facebook, MySpace) assist participants in forming social connections, while enabling collaborative knowledge sharing, idea generation, creative production and peer-to-peer feedback (Dron \& Anderson, 2009; Greenhow, 2011). Several authors and researchers have adopted a networked learning perspective as a conceptual framework for teaching, learning and communication with social media (Haythornthwaite \& Andrews, 2011). By adopting a networked learning perspective, online spaces and virtual communities can be seen to provide important connections for individuals and that the interpersonal interaction that occurs provides important benefits such as improved satisfaction at work, extended social and professional connections and opportunities for social commentary. Therefore, social technologies hold enormous promise for enhancing, enriching, and extending traditional paradigms of professional learning, which, due to resource constraints and time limitations are moving to virtual spaces. Additionally, research on informal learning within SNS contexts suggests that participation in virtual communities fulfils important networking functions and generates social capital (Boyd \& Ellison, 2007). Also, as mobile internet capabilities progress, users more often share information anywhere, anyhow, anytime, which makes communication via SNSs increasingly prevalent among all ages (Cochrane \& Narayan, 2011).

Another result of the ubiquity and uptake of social networking tools is a cultural shift from consumption of new media to creative production, participation and engagement in collaborative networks with activity centered on shared interests or knowledge domains (Doherty, 2011). Austin \& McDaniels (2006) identified the ability to cultivate professional networks as a critical skill for lifelong learning and digital participation. For academics and 
teachers, the ability to communicate in virtual spaces and engage in professional networking is a valued skill that is enabled by social media. Lecturers and teacher educators are now using microblogging platforms to source teaching resources and create avenues for dialogue through blogs, wikis and SNS such as Facebook (Conole, 2010). These trends in social media adoption provide evidence that teachers are leveraging SNS for personal and professional reasons. To review current practice in his area, the primary research questions were as follows: In what ways are teachers using social media and microblogging tools to engage in networking and professional learning? What are academics' motivations for professional networking and what do they perceive as the benefits?

\section{Methodology : A scoping review}

To advance this line of inquiry, the approach was to assess the impact of social media and microblogging tools in supporting professional learning, and to consider cases of how digital tools are being used by teachers and academics in higher education. Social networking technologies, such as Web 2.0 tools, provide a platform for social interaction, enabling social and interpersonal relationships and as a consequence, support informal learning and knowledge sharing across temporal and spatial boundaries. By viewing social media in this way, we shed light on several technological options that facilitate collegiality and informal learning. To illustrate the potential benefits of social media and microblogging, a scoping review of articles published in refereed journals between 2009 and 2015 was carried out. Articles were chosen on the basis of whether they reported use of SNS's for networking, community building, professional development and knowledge sharing. The framework outlined by Boote \& Beile (2005) was used as a guide for the review as according to these authors "To be useful and meaningful, education research must be cumulative; it must build on and learn from prior research and scholarship on the topic (Boote \& Beile, 2005: 3). The approach adopted included criteria for inclusion or exclusion, a synthesis of literature and discussion of significance. The criteria for inclusion were first, articles on SNS used by teachers for professional dialogue, and articles on how and why teachers and academics engage in microblogging for informal networking and sharing of knowledge. The second criteria was currency i.e. recent articles, and the third criterion was publication in peer reviewed journals. Only high quality journals were selected, including:

- Computers and Education

- Journal of Computer Assisted Learning

- Australasian Journal of Educational technology

- International Review of Open and Distance Learning

- British Journal of Educational Technology

- Internet and Higher Education

- $\quad$ Research in Learning Technology 
A scan of these journals provided several sources which was augmented by a search of Scopus and Web of science, giving a total of 218 articles between 2009 and 2015. This was culled down and limited to empirical studies and excluded theoretical papers. Articles detailing student perceptions of social media or the impact of microblogging on teaching and learning were also eliminated. After removing duplicated articles only 14 articles presented evidence based research on professional learning mediated by social networking tools. Table 1 presents a summary of the selected articles with a summary of findings.

Table 1: Exemplars of Social Media in Higher Education

\begin{tabular}{|c|c|c|c|}
\hline Authors & $\begin{array}{l}\text { SNS \& } \\
\operatorname{tool}(s)\end{array}$ & Methodology & Outcomes/findings \\
\hline $\begin{array}{l}\text { Carpenter \& } \\
\text { Krutka (2014) }\end{array}$ & Twitter & $\begin{array}{l}\text { Survey conducted of K-12 } \\
\text { educators regarding use of } \\
\text { Twitter for professional } \\
\text { development }\end{array}$ & $\begin{array}{l}\text { Participants reported the benefits of } \\
\text { Twitter for access to ideas, } \\
\text { knowledge and information; } \\
\text { connections to sources of expertise } \\
\text { and reducing sense of isolation }\end{array}$ \\
\hline Burden (2010) & $\begin{array}{l}\text { Wikis, } \\
\text { voicethread, } \\
\text { 3D immersive } \\
\text { worlds }\end{array}$ & $\begin{array}{l}\text { Conceptual framework for } \\
\text { teacher reflection, publishing } \\
\text { collaboration \& knowledge } \\
\text { construction }\end{array}$ & $\begin{array}{l}\text { Affordances of Web } 2.0 \text { were seen as } \\
\text { valuable for professional learning }\end{array}$ \\
\hline $\begin{array}{l}\text { Cahn, } \\
\text { Benjamin } \\
\text { Shanahan } \\
(2013)\end{array}$ & $\begin{array}{l}\text { Blogs, } \\
\text { Facebook, } \\
\text { Social } \\
\text { bookmarking; } \\
\text { Twitter; Video } \\
\text { sharing sites, } \\
\text { wikis }\end{array}$ & $\begin{array}{l}\text { Search of } 154 \text { medical school } \\
\text { websites in the USA for } \\
\text { media used by academic } \\
\text { developers }\end{array}$ & $\begin{array}{l}\text { Most frequent uses are Facebook, } \\
\text { blogs and Twitter for information } \\
\text { sharing and networking }\end{array}$ \\
\hline $\begin{array}{l}\text { Cochrane } \\
\text { Narayan } \\
(2011)\end{array}$ & $\begin{array}{l}\text { Mobile web } \\
2.0 \text { tools }\end{array}$ & $\begin{array}{l}\text { Podcasting, vodcasting, } \\
\text { Skype blogs, Twitter }\end{array}$ & $\begin{array}{l}\text { Community of Practice model of } \\
\text { professional development using } \\
\text { mobile web } 2.00 \text { tools and social } \\
\text { technologies, raised awareness }\end{array}$ \\
\hline $\begin{array}{l}\text { Duncan- } \\
\text { Howell (2013) }\end{array}$ & $\begin{array}{l}\text { SNS } \\
\text { Facebook and } \\
\text { Tumblr }\end{array}$ & $\begin{array}{l}\text { Survey of teachers use of } \\
\text { SNS }\end{array}$ & $\begin{array}{l}\text { Teachers used SNS as informal } \\
\text { sources of professional learning and } \\
\text { found them to be convenient and } \\
\text { relevant }\end{array}$ \\
\hline $\begin{array}{l}\text { Ebner, } \\
\text { Lienhardt. } \\
\text { Rohs \& Meyer } \\
(2010)\end{array}$ & $\begin{array}{l}\text { Microblogging } \\
\text { Twitter/blogs }\end{array}$ & $\begin{array}{l}\text { A microblogging platform } \\
\text { was used for process oriented, } \\
\text { informal learning }\end{array}$ & $\begin{array}{l}\text { Attempts to establish a process- } \\
\text { oriented environment } \\
\text { microblogging tools had limited } \\
\text { success, but enabled staff envision } \\
\text { new forms of community and virtual } \\
\text { presence }\end{array}$ \\
\hline
\end{tabular}




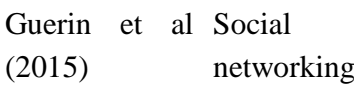

Holmes et al Twitter

(2013)

Mewburn \& Blogs

Thomson

(2013)

Veletsiansos Twitter/social Analysis of Tweets/Blogs

\& Navarette networking

(2012)

Carpenter \& Twittter

Krutka (2014)

Stephansen \& Twitter

Couldry

(2014)

Lupton,

Social media
and Twitter

McPherson, Twitter

Budge \&

Lemon,

(2015). knowledge social media academic practice
Investigation of blogging Advantages of blogging for effects in doctoral education professional development includes community building and connectivist learning

Analysis of the tweets of 30 Twitter found to be accessible source influential users of the of new ideas and social support for medium teachers

Sampling of academic blogs Blogs were found to serve multiple using snowball method and informal purposes in analysis of blogs content academia:dialogue reflection on academic work and research; dissemination of ideas and publications, mentoring, sharing career \& teaching advice

Academics use Twitter and social networks for sharing information, expansive learning, requesting assistance, connecting and networking

Survey of K-12 educators Participants reported the benefits of regarding use of Twitter from Twitter for access to ideas, professional development knowledge and information; connections to sources of expertise and reducing sense of isolation

Action research project to Students and teachers contributed to a engage a team in developing Twitter feed to create a virtual a virtual community to share community and digital story circle

Large survey on 711 Benefits for academic work included academics about their use of connecting and establishing networks, giving and receiving support

Qualitative research Twitter as a means of informal presenting vignettes of networking and community building for professional learning.

Table 2 shows the various reasons behind teachers' use of Twitter and the benefits they perceived from these virtual interactions. The findings indicate that networking activities result in a range of benefits to participants, going beyond access to new ideas and information. Many found it an antidote to professional isolation and a sense of being 
connected to global audience of experts. These relational benefits are described in several studies and are motivated by the desire to go beyond local sources and contacts and solicit crowd-sourced feedback from a global audience.

Table 2: Motivations for networking and its benefits

\begin{tabular}{|c|c|c|}
\hline Motivation & Benefits & Authors \\
\hline $\begin{array}{l}\text { Access to new ideas and } \\
\text { resources }\end{array}$ & Reduces professional isolation & $\begin{array}{l}\text { McPherson, Budge \& } \\
\text { Lemon, (2015). }\end{array}$ \\
\hline $\begin{array}{l}\text { Conversing with likeminded } \\
\text { colleagues and experts }\end{array}$ & $\begin{array}{l}\text { Multiple perspectives and } \\
\text { diverse ideas }\end{array}$ & $\begin{array}{l}\text { Carpenter \& Krutka } \\
(2014)\end{array}$ \\
\hline $\begin{array}{l}\text { Professional discussion and } \\
\text { support }\end{array}$ & $\begin{array}{l}\text { Access to cutting edge ideas } \\
\text { and current trends }\end{array}$ & $\begin{array}{l}\text { Mewburn \& Thomson } \\
\text { (2013) }\end{array}$ \\
\hline $\begin{array}{l}\text { Connecting globally, learning } \\
\text { about innovative } \\
\text { developments }\end{array}$ & $\begin{array}{l}\text { Getting beyond the silos of their } \\
\text { own university/school }\end{array}$ & $\begin{array}{l}\text { Stephansen \& Couldry } \\
\text { (2014) }\end{array}$ \\
\hline $\begin{array}{l}\text { Social conversation and } \\
\text { desire to share resources }\end{array}$ & $\begin{array}{l}\text { Expanding one's connections; } \\
\text { collaboration with a global } \\
\text { audience }\end{array}$ & $\begin{array}{l}\text { Ebner, Lienhardt. Rohs } \\
\& \text { Meyer (2010) }\end{array}$ \\
\hline
\end{tabular}

\section{Findings of the Review}

Networked practices of academics in the articles surveyed showed commonality in a number of themes. The most significant use of Twitter was for exchange of information, team and community building, enhancement of dialogue and development of collegial networks for improved productivity (Stephansen \& Couldry, 2015; Veletsianos \& Navarrete, 2012). Blogs and wikis were created as a virtual space for sharing ideas and information and to build community (Mewburn \& Thomson, 2014; Ebner et al 2010). Cahn et al, (2013) and Cochrane \& Narayan, (2011) demonstrated that academics achieved multiple benefits from mobile Web 2.0, blogs and Twitter for information sharing and networking. The potential of social networking and microblogging tools for developing relationships and enabling swift communication provided academics with access to and use suite of tools to engage in professional conversations, shared ideas and resources (Ebner et al, 2010; Lupton, 2014). The social web is therefore a way of creating opportunities for engagement and networking going beyond traditional channels such as email or face-toface conversation. For academics in higher education, creating web presence was seen as a strategic way to form networks and disseminate information, compare practices, raise awareness, foster innovation, build influence and effect change (Holmes et al, 2013). By providing open, alternative venues for idea sharing, social networking services foster 
informal spaces for professional conversations. Teachers want to join and participate in online communities and engage in informal knowledge practices and their motivations are varied (Table 2). The evidence shows that that there is much potential value in using microblogging and SNS to enhance communication, share knowledge, and build networks within and across virtual spaces and disciplinary boundaries. The benefits of this reciprocal sharing are that it leads to strong relational ties by expanding users' professional circles as well as increasing the frequency of interpersonal contact and collegiality. Community outreach, visibility and partnerships are all important aspects of school and university culture and scholarship. By building social capital though participation and communication in networks, academics can extend their knowledge and engage in professional growth and development.

\section{Conclusions: Networks for enabling informal professional learning}

Web 2.0 has brought to education a suite of user-friendly tools for information access and aggregation, openness, tagging, portability, reuse, multichannel distribution, syndication and content creation. They all improve openness, communication, networking and sharing. In this article, global examples of how microblogging and social networking tools are being used globally are presented. By fueling a move towards informal networked forms of professional learning, digital tools and microblogging promote socio-experiential and grassroots communities of learning that support professional learning and are aligned to the demands and challenges of the knowledge era and networked society.

The examples show that there is a need to revise professional learning to an informal, participatory networked endeavour creating learning communities and opportunities for informal learning and knowledge sharing, rather than a top-down skills-based approach. This review has addressed a gap in the literature and advances understanding of the value of social media for relational connections and informal professional development. Few studies have focused on how teachers make use of social networking tools to share knowledge, create learning communities and access resources to expand their professional circles. By embracing social media tools, teachers are now part of a complex, dynamic techno-cultural system, using resources that lend themselves to knowledge sharing and innovation. Future research should investigate patterns of networking that expand academics' knowledge and skills base and whether these connections are cross-institutional, cross-faculty or global.

\section{References}

Austin, A. E., \& McDaniels, M. (2006). Preparing the professoriate of the future: Graduate student socialization for faculty roles. In J. C. Smart (Ed.), Higher education: Handbook of theory and research, XXI (pp. 397-456). Dordrecht, The Netherlands: Springer 
Boote D. N., Beile P. (2005). Scholars before researchers: On the centrality of the dissertation literature review in research preparation. Educational Researcher, 34(6), 3 15. doi:10.3102/0013189X034006003

Boyd, D. M., \& Ellison, N. B. (2007). Social network sites: Definition, history, and scholarship. Journal of Computer-Mediated Communication, 13(1), 210-230. doi:10.1111/j.1083-6101.2007.00393.x

Burden, K. J. (2010). Conceptualising teachers' professional learning with web 2.0. Campus-Wide Information Systems, 27(3), 148-161.

Cahn, P. S., Benjamin, E. J. \& Shanahan, C. W. (2013) Uncrunching' time: medical schools' use of social media for faculty development. Med Educ Online 2013, 18: 20995 - http://dx.doi.org/10.3402/meo.v18i0.20995

Carpenter, J. P., \& Krutka, D. G. (2014). Engagement through microblogging: Educator professional development via twitter. Professional Development in Education, , 1-22. doi:10.1080/19415257.2014.939294

Cochrane, T., Narayan, V. (2011) Defrosting professional development: Reconceptualising teaching using social learning technologies. Research in Learning Technology, 19 1, 2011, retrieved September at http://www.researchinlearningtechnology.net/index.php/rlt/article/view/7796/10503

Conole, G. (2010). Facilitating new forms of discourse for learning and teaching: Harnessing the power of Web 2.0 practices. Open Learning, 25(2), 141-151.

Council of Australian Directors of Academic Development (ND) Retrieved April $4^{\text {th }}, 2016$ at http://www.cdc.gov/socialmedia/tools/guidelines/socialmediatoolkit.html

Di Napoli, R., Fry, H., Frenay, M., Verhesschen, \&Verburgh, A. 2010. Academic development and educational developers: Perspectives from different European higher education contexts. International Journal for Academic Development, 15(1): 7-18.

Doherty, I. (2011). Evaluating the impact of educational technology professional development upon adoption of Web 2.0 tools in teaching. Australasian Journal of Educational Technology, 27(3), 381-396. http://www.ascilite.org.au/ajet/ajet27/doherty.html

Dron, J., \& Anderson, T. (2009). How the crowd can teach. In S. Hatzipanagos \& S. Warburton (Eds.), Handbook of research on social software and developing community ontologies (pp. 1-17). Hershey, PA: IGI Global Information Science.

Duncan-Howell, J. (2010). Teachers making connections: Online communities as a source of professional learning. British Journal of Educational Technology, 41(2), 324-340. doi:10.1111/j.1467-8535.2009.00953.x

Ebner, M., Lienhardt, C., Rohs, M., \& Meyer, I. (2010). Microblogs in higher education A chance to facilitate informal and process-oriented learning? Computers \& Education, 55(1), 92-100. doi:http://dx.doi.org/10.1016/j.compedu.2009.12.006 
Gee, J.P. (2007) 'Affinity Spaces: From Age of Mythology to Today's Schools', in Good Video Games + Good Learning: Collected Essays on Video Games, Learning, and Literacy, New York, NY, United States, Peter Lang. pp. 87-103.

Greenhow, C. (2011). Online social networking and learning. International Journal of Cyber Behavior, Psychology and Learning, 1(1), 36-50.

Guerin, C., Carter, S \& Aitchison, C. (2015) Blogging as community of practice: lessons for academic development? International Journal for Academic Development, 20 (3), 212-223

Hakkarainen, K., Palonen, T., Paavola, S., Lehtinen, E. (2004). Communities of networked expertise. Elsevier, Amsterdam (2004)

Haythornthwaite, C. A., \& Andrews, R. (2011). E-learning theory and practice. Los Angeles: Sage.

Holmes, K., Preston, G., Shaw, K., \& Buchanan R. (2013) 'Follow me': Professional Learning for the digital age. Australian Journal of Teacher Education. 38, 2:54-65

Jenkins, H., Clinton, K., Purushotma, R., Robinson, A. J., \& Weigel, M. (2006). Confronting the challenges of participatory culture: Media education for the 21st $\begin{array}{llll}\text { century. } & \text { MacArthur } & \text { Foundation. } & \text { Retrieved }\end{array}$ http://www.digitallearning.macfound.org/

Kimmons, R., \& Veletsianos, G. (2015). Teacher Professionalization in the Age of Social Networking Sites: Identifying Major Tensions and Dilemmas. Learning, Media, and Technology, 40(4), 480-501.

Lee, M. J. W., \& McLoughlin, C. (2010). Beyond distance and time constraints: Applying social networking tools and Web 2.0 approaches to distance learning. In G. Veletsianos (Ed.), Emerging Technologies in Distance Education. Athabasca University Press, Edmonton, AB (2009), pp. 61-87.

Lock, J.V. (2006). A New Image: Online Communities to Facilitate Teacher Professional Development. Journal of Technology and Teacher Education, 14(4), 663-678. Chesapeake, VA: Society for Information Technology \& Teacher Education.

Lupton, D (2014) 'Feeling Better Connected': Academics' Use of Social Media. Canberra: News \& Media Research Centre, University of Canberra.

McPherson, M., Budge, K., Lemon, N (2015). New practices in doing academics development. Twitter as an informal learning space. International Journal for Academic Development, 20(2): 126-136

Mewburn, I., \& Thomson, P. (2013). New practices in doing academics development: an analysis of audiences, purposes and challenges. Studies in Higher Education, 20(8), 1105-1119. doi:10.1080/03075079.2013.835624 
Paavola, S., Lipponen, L. \& Hakkarainen, K. (2004). Modelling innovative knowledge communities: a knowledge-creation approach to learning. Review of Educational Research, 74, 557-576.

Prestridge, S. J. (2014) A focus on students' use of Twitter- their interactions with each other, content and interface. Active Learning in Higher Education, Vol. 15(2), pp. 101115

Schroeder, A., Minocha, S., \& Schneider, C. (2010). The strengths, weaknesses, opportunities and threats of using social software in higher and further education teaching and learning. Journal of Computer Assisted Learning, 26(3), 159-174.

Stephansen, H. C. and Couldry, N. (2014) Understanding micro-processes of community building and mutual learning on Twitter: a 'small data' approach. Information, Communication \& Society, 17 (10). 1212-1227. ISSN 1369-118X.

Veletsianos, G. (2012). Higher education scholars' participation and practices on Twitter. Journal of Computer Assisted Learning, 28(4), 336-349.

Veletsianos, G. \& Navarrete, C. (2012). Online Social Networks as Formal Learning Environments: Learner Experiences and Activities. The International Review of Research in Open and Distance Learning, 13(1), 144-166. 